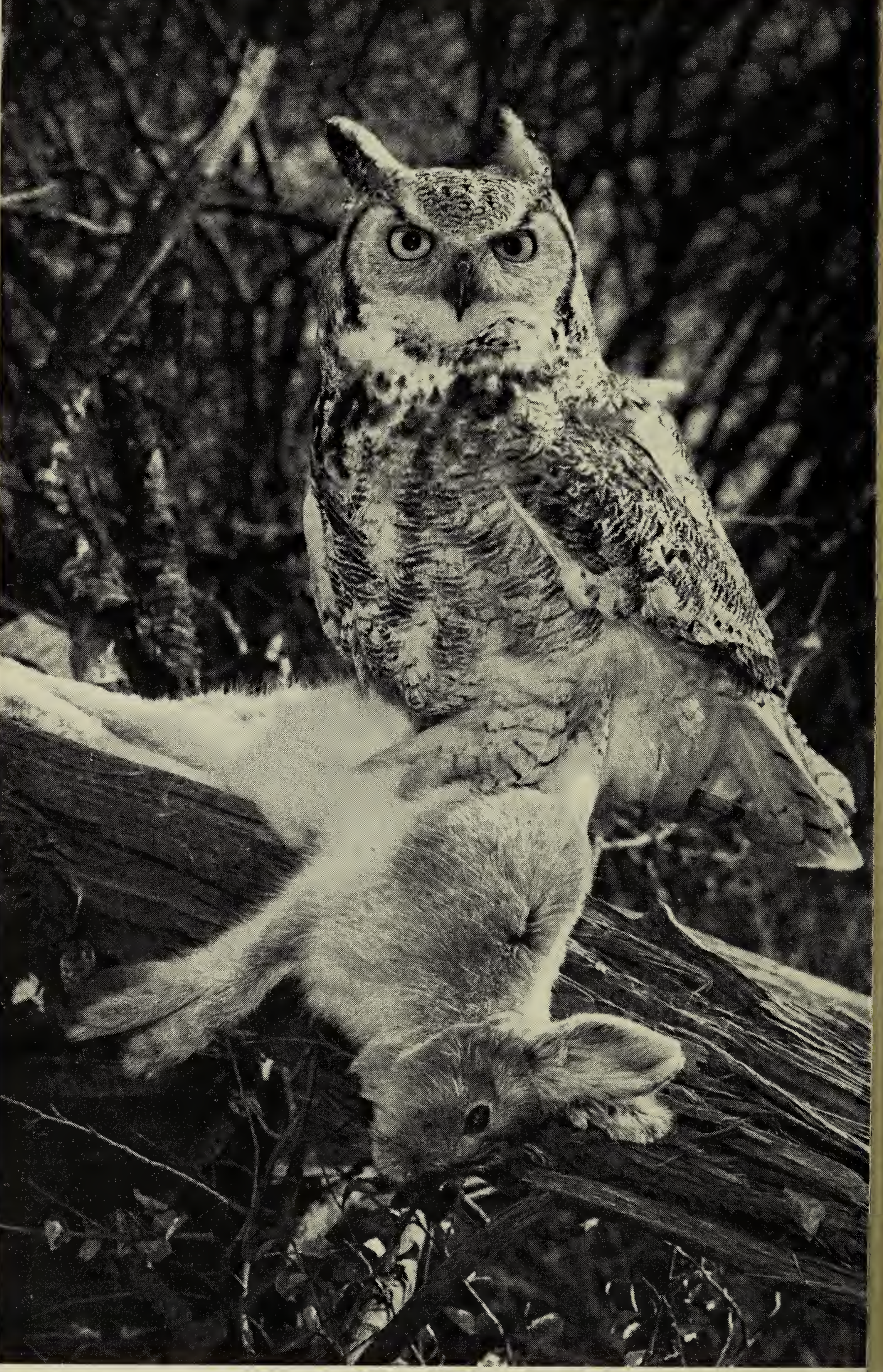

Great Horned Owl

Hans Dommasi 


\title{
LAND USE PLANNING \\ IN CYPRESS HILLS PROVINCIAL PARK, SASKATCHEWAN
}

\author{
ELIZABETH McGREGOR, \#14-96 Hanbidge Crescent, \\ Regina, Saskatchewan S4R 6N2
}

Planning for land use in Cypress Hills Provincial Park is representative of the problems faced in resolving land use conflicts in provincial parks throughout Saskatchewan. Cypress Hills Provincial Park, which encompasses 44 square kilometers (17 sq. mi.) of the Centre Block and 135 square kilometers ( 53 sq. mi.) of the West Block of the Cypress Hills, provides recreational opportunities which are otherwise unavailable in southwestern Saskatchewan. Opportunities and facilities include campgrounds, cottages, institutional camps, golfing, swimming, fishing, hiking and horseback trail riding. Winter activities include downhill skiing, snowmobiling and cross-country skiing. Hunting of moose, elk, deer and game birds is licensed in the Park.

As in most provincial parks and ecreation areas throughout Saskatchewan, the number of visitors to Cypress Hills Provincial Park is increasing annually. In 1976, an esimated 241,000 people visited the ark. This represented an increase of percent since 1972. The number of isitors to Fort Walsh National Historic Site, which is adjacent to the ark boundary, was estimated at 29,30 in 1976, an increase of 34 percent ince 1972. Accompanying this inrease in visitors is an increased denand for visitor accommodation, serices and recreational facilities.

Potential developments in the egion would likely result in an inrease in visitors to the Saskatchewan nd Alberta Cypress Hills Parks. The roposed National Grasslands Park is bout $180 \mathrm{~km}$ southeast of Cypress Hills Provincial Park. An alternate ourist route south of the ransCanada Highway has been roposed which could link the Albera and Saskatchewan Parks, the proposed National Park and points to the east. Access to this route could be provided at various points on the TransCanada Highway including roads adjacent to the Centre and West Blocks. These developments would also increase the demand for recreational opportunities and facilities in the Provincial Parks.

In addition to these recreational interests, there are other demands for land use in the Park. Local residents with to continue traditional land uses such as livestock grazing, mowing and lumbering. Land adjacent to the Park is primarily crown land leased by ranchers for grazing livestock. Since the private land holdings of these ranchers are relatively small, the Park is considered important for grazing. The demand for hay depends upon annual fluctuations in the amount of precipitation. In drier years, hay from the plateau is in greater demand. Cutting of white spruce and lodgepole pine occurs primarily in the West Block.

The Cypress Hills are also of interest to scientific and education groups for interpretation of natural processes and historical events. The University of Regina has leased 2.6 square kilometers (1 sq. mi.) of land in the West Block to serve as a field station for classes and research projects. The Saskatchewan International Biological - Conservation Terrestrial Committee identified two areas in the West Block as potential ecological reserves.

Mineral interests in the Park include gravel extraction and oil and gas leases. The Saskatchewan Oil and Gas Corporation has leased 13 square kilometers (5 sq. mi.) of land in the West Block for petroleum and natural gas exploration. These ten year leases were obtained in 1974. 


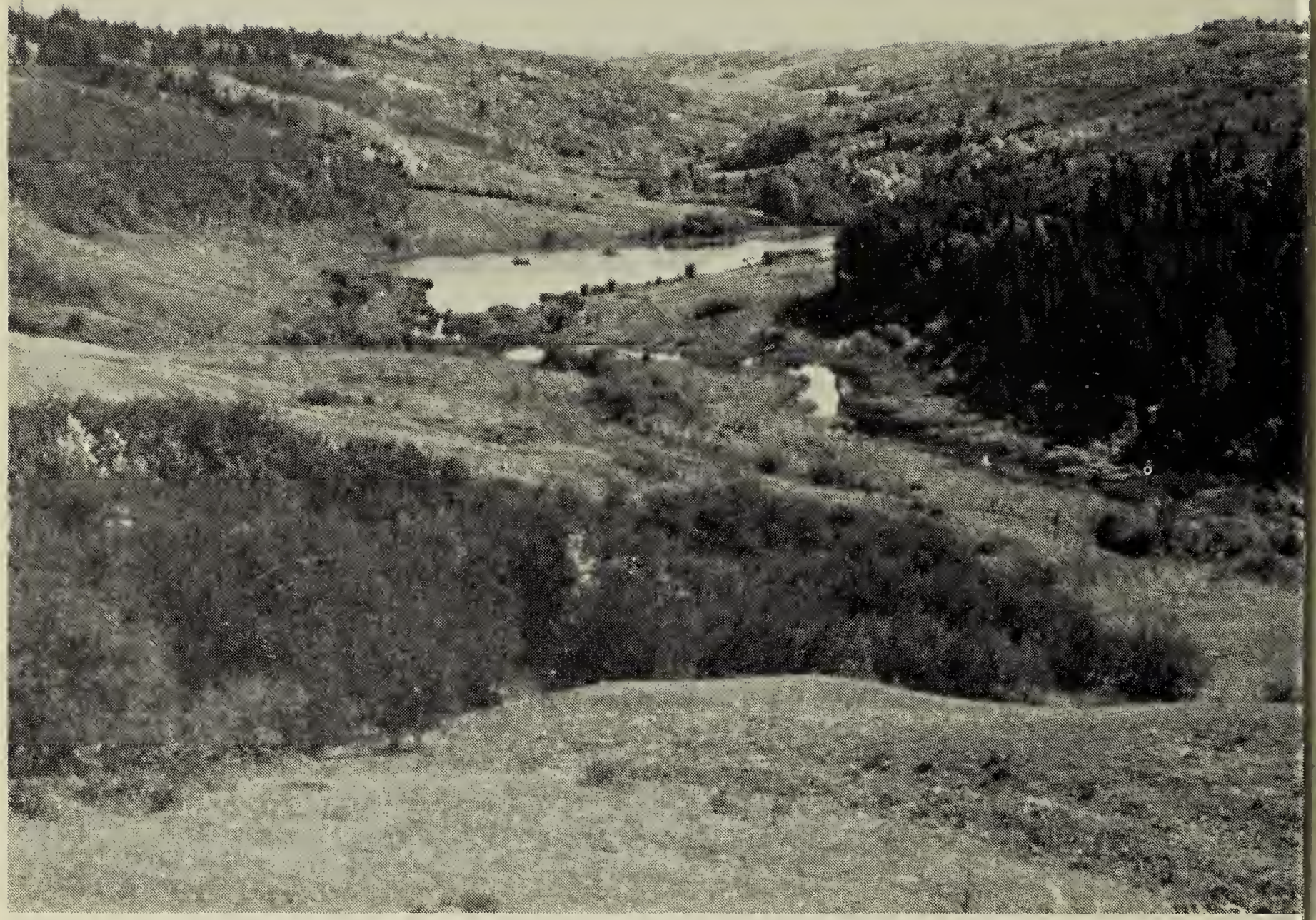

Valley of Lonepine Creek, looking south

Elizabeth McGrego

Coal was extracted from the Hills for local use during the early 1900's. Currently, there is no expressed interest in the coal deposits. Geological Survey of Canada conducted a series of tests in the Hills in 1976. The purpose was to test methods for prospecting for buried uranium deposits. Uranium rich coal seams and radioactive fossil bones have led to speculation about the existence of uranium deposits in the Cypress Hills.

Water resources support wildlife and domestic livestock. Water is stored in Adams Lake and released for downstream irrigation projects. Stocked streams and lakes provide recreational fishing.

The Park cannot provide maximum resource use to satisfy all of these interests. A plan for future use of the Park is essential. Several questions are critical in planning for land use in the Cypress Hills. What is the purpose of the Park? What are the potential effects of an increase in recreationa activity in the Park? Can the Park sup port resource uses such as grazing lumbering and haying in addition ti recreational activities? What are the potential effects of continued graz ing, lumbering, haying and hunting

In this article, I will review the re cent planning activities for land use i the Park, delineate the significan features of the Park, and examine th implications of some of the recen recommendations for Park use.

\section{Administration}

The Cypress Hills have long beel valued for their resources. For 7 years, parts of the Cypress Hills hav received protection. Due to concer about diminishing resources, the firs Federal Forest Reserves wer designated in 1906. By 1916, 45 square kilometers (177 sq. mi.) of th Saskatchewan and Alberta Cypres Hills were reserved under The Domi nion Forest Reserves and Parks Act. II 
leases are administered by the department of Mineral Resources.

The management of various land uses by a number of agencies can result in management actions which conflict with one another and with the objectives of park use. Although there are channels of communication between agencies, programs for managing forest, grassland, wildlife and recreation are often carried on independently of one another. Coordination of these programs often depends upon regional and park administrators. To ensure that park land use is consistent with the purposes for which parks are designated, a coordinated planning and management program must be developed.

\section{Planning}

The most recent planning for land use in Cypress Hills Provincial Park includes a master plan and a master plan study. In 1969, a master plan was prepared for Cypress Hills Provincial Park and Provincial Forest. ${ }^{2}$ The plan recommended that the Centre Block be managed as a recreation area and the West Block as a natural area. Although the plan was never approved, it did result in upgrading recreational facilities by provision of a visitor centre, additional campgrounds, and staff and public accommodation in the Centre Block.

In the 1970's there was continued recognition of the need for management plans for the Park and Forest. As the Tourism and Recreation Planning Branch did not have sufficient time or staff to prepare a master plan, a consultant was contracted to undertake a master plan study for the Cypress Hills Provincial Park and Forest.

Although the master plan study did not provide adequate information to enable development of management policies for the Park, it did provide a basis for public discussion of future land use in the Park. ${ }^{3}$ A summary of the master plan study prepared by the Tourism and Recreation Planning Branch was distributed to the public in the spring of 1976. Information meetings and public hearings to dis- cuss the proposed plan were held in Swift Current, Maple Creek and Cypress Hills Provincial Park in June, 1976. These meetings were conducted by a Panel and Task Force. Panel members represented the Departments of Tourism and Renewable Resources, Municipal Affairs and the Environment. The Task Force included the Park Superintendent and personnel from the Forestry Branch, Fisheries and Wildlife Branch, and Tourism and Recreation Planning Branch.

Following the public hearing, the Panel and Task Force members evaluated information provided by the public hearings, the comment sheets, and the master plan study in order to prepare guidelines for management of the Park. Following approval of these guidelines, a master plan for the Park is to be prepared.

Recommendations of the Panel and Task Force on the Cypress Hills Provincial Park public hearings were presented and discussed at a public meeting held in the Park in August, 1977. ${ }^{4}$ These recommendations have been submitted to DTRR for consideration and action. No planning process for preparation of a master plan for the Park has yet been approved.

Coincidentally, the Alberta government is currently preparing a master plan for the Alberta Cypress Hills Provincial Park. The planning program is somewhat similar to the process undertaken in Saskatchewan, and the responsible agency is currently preparing policy recommendations which will provide a basis for preparing a park master plan. The Saskatchewan and Alberta governments are each planning for future management in the respective Cypress Hills Parks. Recent attempts to cooperate in planning include discussion about access and circulation and ungulate management. Because the Cypress Hills are a physical unit with similar environmental and cultural features throughout, further discussion is required to examine the potential influences of plans for land use in the adjacent Parks. 
A master plan is a control document which should serve as a long range policy guide for management of park resources and programs. The master plan is the result of a planning process which can be divided into four phases. First, an inventory and evaluation of park resources and values is essential to planning for management. Secondly, regional, political and economic constraints affecting the park require analysis. This inventory and analysis enables formulation of the purposes and objectives of the park and how it will be used by people. ${ }^{5}$ Guidelines for applying these purposes and objectives to the park can then be developed.

Although there has been no detailed inventory of the Park resources, the Cypress Hills have been the subect of numerous botanical, wildlife and geological studies which have dentified some of the significant eatures of the Park.

\section{Significant Features}

The Cypress Hills support a diversi$y$ of vegetation not found elsewhere n southwestern Saskatchewan. odgepole pine, white spruce and spen forests grow on the north facng slopes. The more gentle, south acing slopes and the plateau support mixed grass prairie and fescue prairie. orests and wetland complexes grow long stream valleys and gulleys. The fypress Hills thus provide an opporunity to observe plant communities epresentative of grassland, aspen arkland, cordilleran and boreal ommunities normally found over reater latitudes.

A number of plant species are pund in the Cypress Hills which are ot found elsewhere in askatchewan. Plant species which re more typical of the foothills and ocky Mountains are today found in he Hills. Of the 669 vascular plant pecies reported in the Cypress Hills, 6 percent are cordilleran species. ${ }^{6}$ milarly, 8.3 percent of the mosses e representative of montane pecies. ${ }^{7}$ Lodgepole pine is found in iskatchewan only in the Cypress
Hills. The presence of 14 species and two varieties of orchids in such a small area is also of botanical interest. ${ }^{8}$

The presence of fescue grassland is of botanical and scientific interest because much of the fescue grassland in Saskatchewan and Alberta has been cultivated. ${ }^{9}$ Cypress Hills Provincial Park is the only provincial park containing a representative fescue grassland. The fescue grassland, which provides food for elk and deer and cover for small mammals and birds, is also valued for livestock grazing.

Wetland and shrub communities along streams are limited by comparison with acreage of other plant communities in the Hills. These communities provide critical habitat for wild ungulates and trumpeter swans.

The forested slopes of the Hills enhance the scenic quality of the region and provide habitat for animal species not found elsewhere in southwestern Saskatchewan. These forest stands are also a source of lumber and poles for use in the immediate region.

A habitat inventory of southwestern Saskatchewan by the Saskatchewan Wildlife Division identified the Cypress Hills as critical habitat for moose, elk, mule deer and white-tailed deer and trumpeter swans. This habitat does not include all of the range used by these animals but it is necessary for maintaining the present populations.

Fisheries and Wildlife surveys in the spring of 1977 indicated a conservative estimate of $80-100$ moose and 600-700 elk in the SaskatchewanAlberta West Block. Estimates of deer population are more difficult to obtain because of the highly varied topography. The Centre Block supports smaller ungulate populations.

Trumpeter swans, at one time considered an endangered species, nest in the Cypress Hills and one other area in Saskatchewan. ${ }^{10}$ The Park provides feeding habitat for doublecrested cormorants and white pelicans which may nest in Cypress Lake south of the Park. The Cypress 


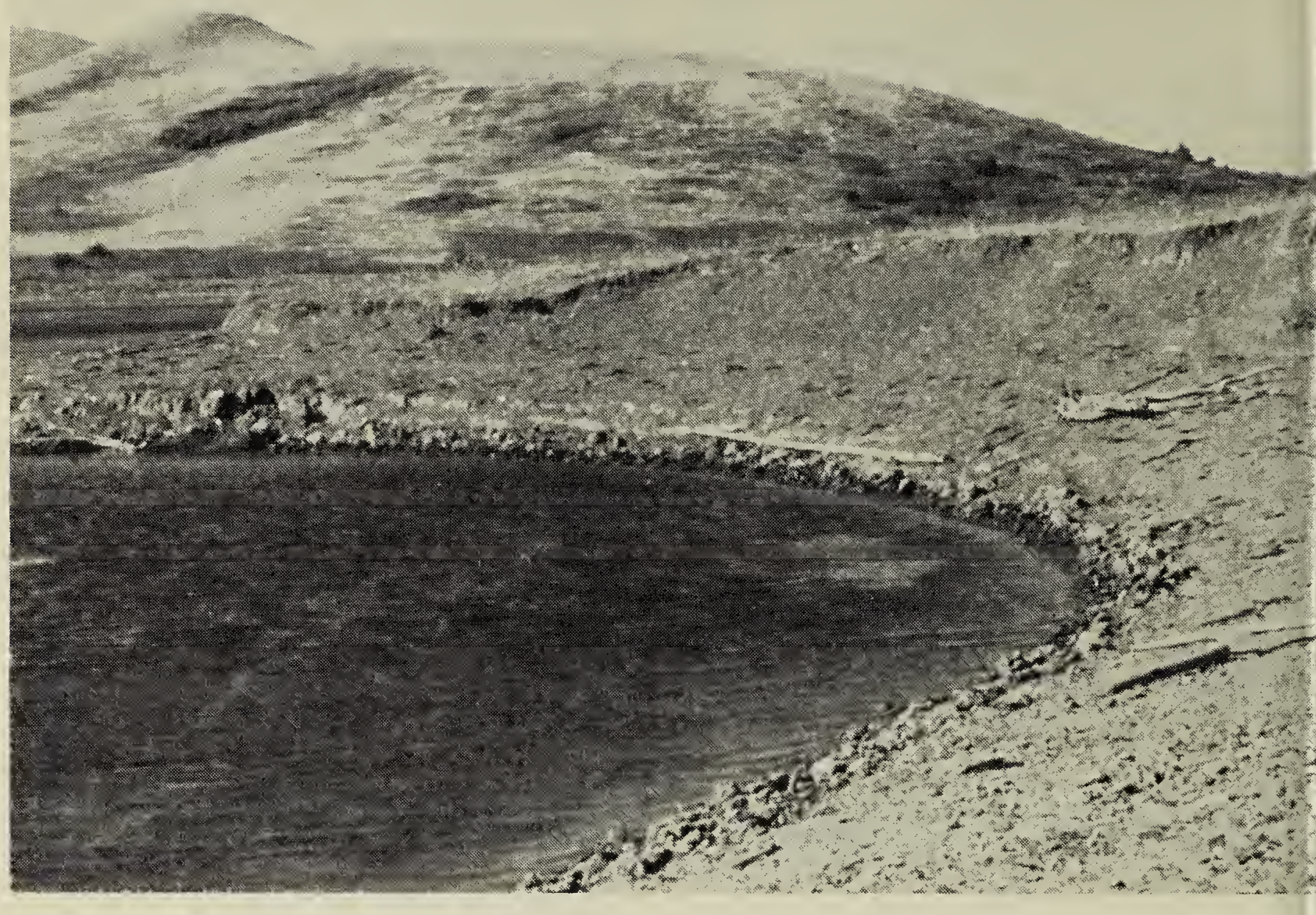

Eroded shoreline of Adams Lake

Elizabeth McGregor

Hills are critical habitat for turkey vultures. MacGillivray's warbler, Oregon junco and Audubon's warbler, which nest in the Park, normally inhabit the mountains. The value of the birds present in the Cypress Hills is not only in those species which may be rare in other parts of the province and surrounding grassland. Equally important is the opportunity to observe birds of many habitats.

The sagebrush pocket gopher, badlands meadow vole and pallid sagebrush vole which are present in the Hills are of interest because they usually inhabit the more arid Missouri watershed. Mammals present in the Cypress Hills which are more likely to be found in aspen parkland, boreal or cordilleran habitats include the American varying hare, striped ground squirrel, little northern chipmunk, Richardson pocket gopher, gray bushy-tailed wood rat, plains red-backed vole, little Rocky Mountain weasel and the Hudson Bay mink. ${ }^{11}$ The status of the northern plains red fox, an inhabitant of aspen parkland, is uncertain in the Hills. The pallid-barred bobcat is an occasional wanderer through the Hills.

Geological formations present in the Hills are not found elsewhere in Saskatchewan; some are unique in Canada. These formations remainer after glaciation.

The cultural heritage of the Hills is also a significant feature of the Park Accounts of the pre-European landscape in the Cypress Hills indicate a rich and varied wildlife resource. The isolated Hills served as a buffer zone between the Saskatchewan and Missour watersheds until fur trading advancer to the Hills in the $1870^{\prime}$ s. Wher resources became scarce on the sur rounding plains, large numbers of Indians and Metis were attracted to the Hills by the relative abundance of wildlife. Many animal species became extinct in the Hills as a result of hun ting, trapping and predator contro programs. ${ }^{1}$ 12 The history of fur trading activities, early settlement anc the North West Mounted Police ir the Hills is presented at Fort Walst 
These general objectives serve as a basis for examination of some of the recommendations of the Cypress Hills Provincial public hearings.

\section{Vegetation Management}

The Panel and Task Force recommended that livestock grazing and haying continue according to approved management plans and that mowing should be used to control shrubby cinquefoil. ${ }^{4}$ What, then, are the current grazing and mowing practices? What are the implications of these practices?

The number of livestock grazed in the West Block is based upon a detailed range management plan prepared in 1954. ${ }^{13}$ This plan recommended the number of livestock to be grazed and management practices for salting, herding, fencing, season of use, and a mowing program to control shrubby cinquefoil. In 1953, 2,358 animal units were grazed in the West Block for 5 months. It was recommended that 1,973 animal units be grazed over a 4 month season. (An animal unit is a mature beef cow with or without a calf.)

By 1967,13 years after the recommended animal unit reduction, 2,400 animal units were still being grazed over a 5 month season. The carrying capacity of the range was adjusted in 1967 to allow for 2 sections of grassland which had been deleted from the West Block and increased the assignment of grazing to brush and aspen acreage. It was recommended that the number of animal units grazed be reduced from 2,400 to 1,900 over a 3 to 5 year period.

Currently, $1900+$ animal units are grazed in the West Block and $300+$ animal units in the Centre Block for 5 months. This assignment is based upon recommendations made in 1954 and 1967 . The numbers of animal units assigned to the grassland communities is that recommended for a fescue prairie. This does not allow for the lower productivity of mixed grass communities on lower slopes, benchland and valley bottoms.
The assignment of animal units in the Cypress Hills assumed that only livestock would be grazed. Brush and aspen stands were included in the range assignment. No allowance was made for the elk, moose, mule deer, and white-tailed deer which inhabit the Hills. No allowance is made for variation in the amount of precipitation from year to year.

Overgrazing can occur if livestock and ungulate numbers are too great to be supported by availabe forage. Overgrazing of palatable species reduces plant vigour which enables other less palatable species to encroach. Thus a change in species composition can occur. A sampling study in the fescue grassland of the Park in September, 1976, revealed differences in species composition between areas under different management practices. ${ }^{14}$ The percentage coverage by fescue in grazed and mowed sites ranged from 7 to 39 percent. In a site which has not been grazed or mowed in recent years, fescue had a mean coverage of 50 percent. June grass and wild oat grass, which increase under grazing in fescue grassland, had a greater mean coverage in the mowed and grazed sites than in the unmowed, ungrazed site. Other species which increased in grazed and/or mowed areas were shrubby cinquefoil, fleabanes, northern gentian, silvery lupine, and prairie selaginella.

Physical damage to shrubs and tree seedlings by livestock also results in decreased productivity. Concentrated use can remove vegetation thus subjecting the soil to wind and water erosion. Frequently used paths can be eroded and form pathways for water runoff which results in gullying. Cattle shelter in tree stands. Thus some aspen groves and spruce stands in the Park have been denuded of understory vegetation by the congregation of cattle. Heavy use of the forage means that less plant fibre is returned to the soil which can in turn result in changes in soil characteristics and reduced productivity.

During the 1950 's, recommendations were made to implement a 


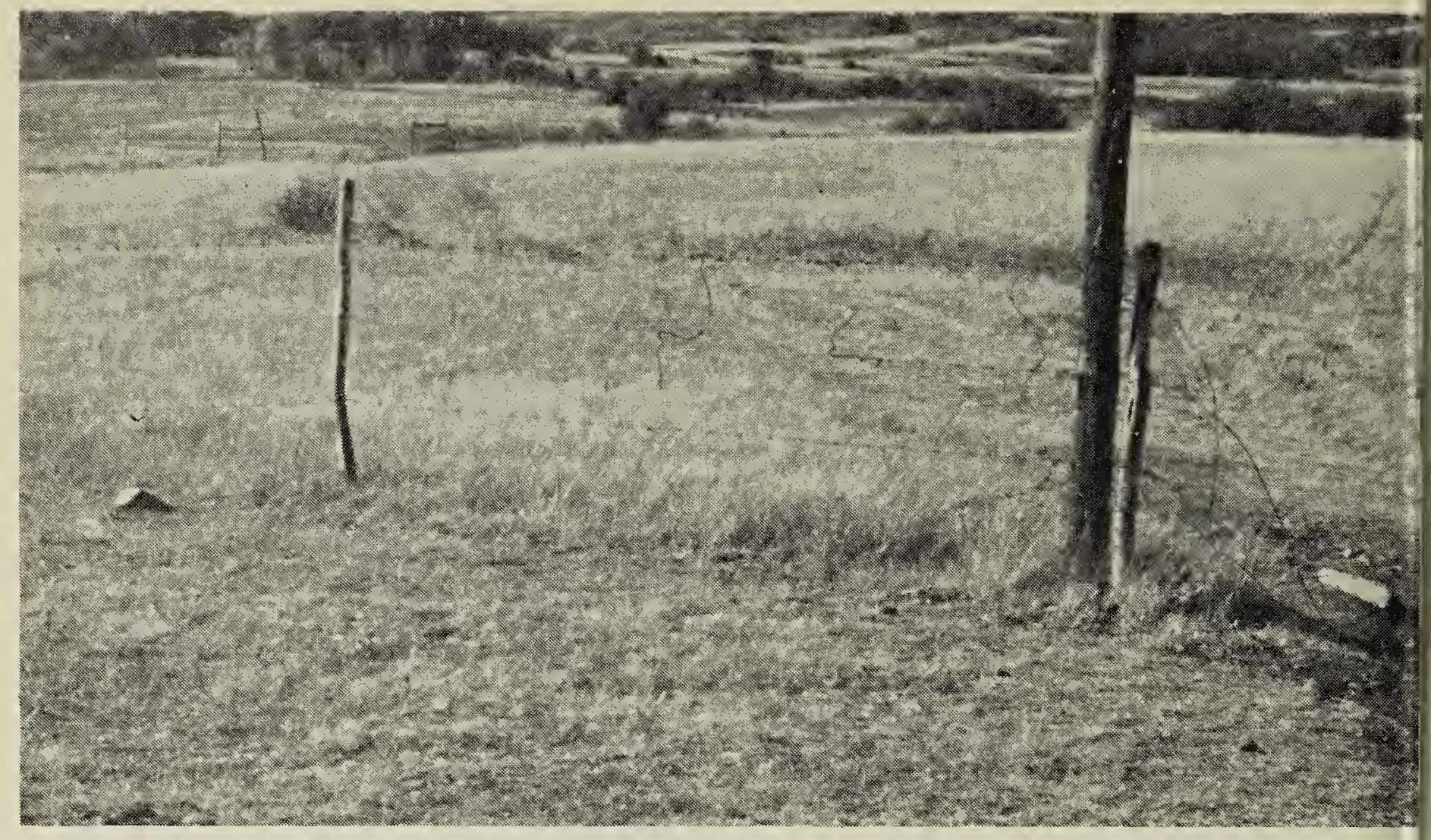

Overgrazed parkland in relation to private ranchland across the fence

Elizabeth McGregor

mature at the present time. Estimates are that some stands will be mature in 20 to 70 years. If stands mature without major disturbances, there could be a decreased diversity of vegetation. Mature stands have sparse understory and provide little food for ungulates. In the absence of fire, timber cutting is a means to rejuvenate forests although patterns and structure of regenerating forest following lumbering would likely differ from those which would reestablish following fire.

The Cypress Hills do not have a high capability for forest production. However, forest harvesting has not been excessive in recent years. Future forest management plans should continue to be consistent with the objectives of maintaining vegetation diversity, conserving water, controlling erosion, providing food and shelter for wildlife and recreational opportunities for viewing a diversity of communities.

Present policy excludes the use of fire as a management tool. Controlled burning could be considered as a means of regenerating forest stands in the Park. Improved forecasting of burning conditions and probable effects and techniques for burning might allow fire to be used in the future.

\section{Wildlife Management}

One recommendation of the Panel and Task Force was that hunting be allowed according to approved management plans. ${ }^{4}$

Results of aerial surveys from 1974 to 1977 indicate an increase in the elk population and a decrease in the moose population. An accurate couni of ungulates is difficult to obtain because of the topographic variation and because surveys of the Alberta and Saskatchewan West Block have not been coordinated in the past. In 1977-78, Alberta and Saskatchewar will coordinate ungulate surveys which will enable a better estimate of ungulate populations. This is a com mendable step towards managemen of the Cypress Hills as an ecologica unit.

Ungulates have few natura predators in the Hills. Records of the increase in the number of elk indicate that the populations can suppor recreational hunting which is one means to control population in. creases. The varied terrain anc accessibility provide an opportunit) for a high quality hunting experience 

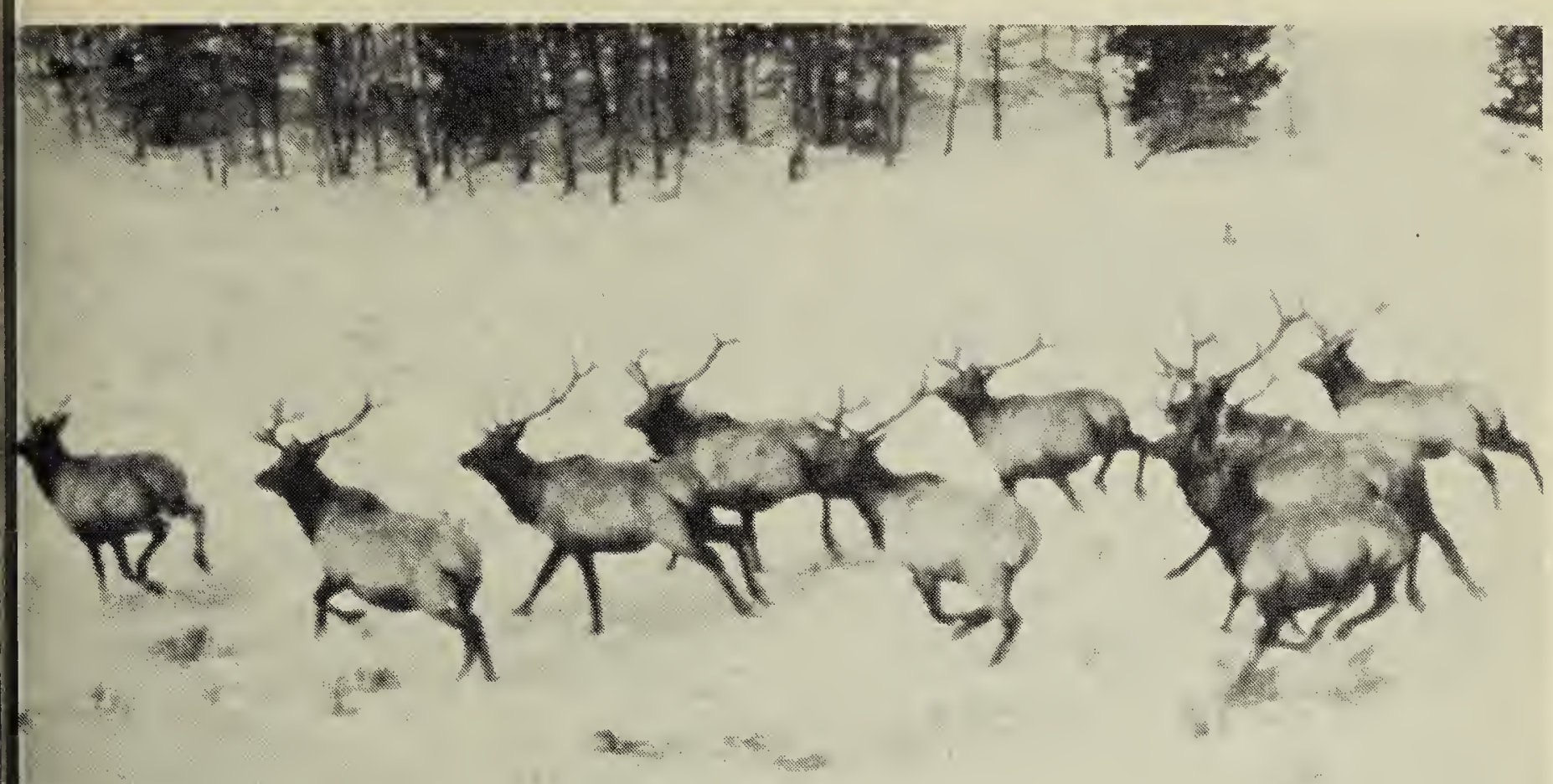

4

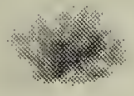

Herd of Bull Elk

Ian McMurchy

Conflicts may arise if there is an exension of other recreational activities nto the hunting season as safety of ecreational users would be a concern.

Although hunting can be used to control ungulate populations, other eatures of ungulate management nust be considered. Browse studies between 1972 and 1977 have inficated a decline in the available prowse in recent years. The extent of fompetition for food between wild ingulates and livestock is not known.

Studies should be undertaken to letermine the number of ungulates present in the Cypress Hills and the easonal use of available range by ach species. These studies, together with a study of effects of livestock razing on vegetation communities, vould enable determination of the number of ungulates and livestock which can be supported in the Park. Browse could be improved by reducng the number of livestock grazed, ontrolling the size of ungulate poplations and by cutting decadent prowse stands to encourage new trowth.

Vehicles can now reach most areas of the Park by roads and fireguards. ontinual arousal of ungulates can cause stress and cause the animals to move to less suitable habitats or restrict animals to smaller ranges. An objective of management of the Park should be to continue to provide habitat for wild ungulate populations. Planning for recreational use and other uses in the Park must consider the potential influences upon ungulate behavior and habitat.

Although no recommendation was made regarding management of trumpeter swans, ${ }^{4}$ an active program should be implemented to protect this species. Planning for recreational use in the Park should provide maximum protection of trumpeter swan habitat. Recreational hiking should be directed away from these areas by careful planning of trails. The possibility of improving potential trumpeter swan nesting and rearing habitat in the Park should be investigated.

Likely because of public interest in hunting, wildlife management in the Hills has concentrated on wild ungulates. A comprehensive wildlife management plan to include other mammals and birds should be prepared. Identification of objectives and research requirements would provide direction for each year's 
management activities and assist in coordination of studies by other agencies involved in preparation of management plans.

\section{Recreation Management}

Several recommendations of the Panel and Task Force are directed towards control of vehicular access and circulation in the Cypress Hills. It was recommended that major travel routes in the Hills be located outside of the Park and that a southern access to Fort Walsh be developed. ${ }^{4}$ Implementing these recommendations would certainly assist in protecting the valued features of the Park.

To reduce the pressure of visitor use it was recommended that campgrounds should not be expanded to meet peak demands on the Park, that a "Sorry-Full" approach be tried and that additional campgrounds which may be required be located outside the Park. ${ }^{4}$

Adopting these recommendations would regulate pressure on the Park. However, planning for recreational use in the Park cannot be isolated from recreational activities in other parts of the Hills. A recommendation to develop Cypress Lake for overflow camping requires careful planning because Heglund Island in Cypress Lake is a critical habitat for many colonial bird species in southwestern Saskatchewan.

A recreation management plan should be prepared to prevent haphazard development of services and facilities in the Park. Effort should also be made to coordinate recreational opportunities in the Saskatchewan and Alberta Parks and Fort Walsh.

\section{Conclusions}

The policy for land use in Cypress Hills Provincial Park has been oriented towards multiple use. Resource uses in the Park currently include grazing, haying, lumbering, gravel extraction, water storage for irrigation and livestock watering, and recreational activities such as hunting, recreational driving, fishing, golfing swimming, hiking, cottaging, anc camping. The Park cannot provid maximum resource use to all interes groups. Continuation of the curren management practices will result ir conflicts between resource users Therefore, a policy must be for mulated to provide for land use in the Cypress Hills.

Concerns expressed at the publi hearings and by managers and ad ministrators of the Park strongly sup port preparation of a master plan fo the Park. The primary managemen objectives should be to protec significant features of the vegetation wildlife and physical features and to provide recreational opportunities ts interpret and study these features Levels of recreational use and othe resource uses such as grazing lumbering, haying and water storag should be compatible with main taining the significant features.

Preparation of policy and a maste plan for Cypress Hills Provincial Par is the responsibility of the Tourisn and Recreation Planning Branch. planner or planning team is depen dent upon an adequate resource in ventory and other agencies fo specific resource management plans Planning for land use in the Cypres Hills is also restricted by staff respon sibilities for other provincial park and recreation areas in Saskatchewan In spite of these difficulties, a mean must be determined to prepare an implement a master plan for th Cypress Hills Provincial Park. Th recommendations of the publi hearings do provide direction fo preparation of a master plan. Many $d$ these recommendations can serve a short term management policies However, short and long term studie of resources and the effects management practices are requirer The Department of Tourism an Renewable Resources should b strongly encouraged to undertak preparation of a master plan fo Cypress Hills Provincial Park. 
'SCACE, R. C. 1972. The Management of a Canadian Plains Oasis: The Cypress Hills Public Reserves. Unpub. Ph. D. Thesis. Univ. of Calgary. 327 pp.

${ }^{2}$ Sask. Dept. of Natural Resources. 1969. Master Plan for Cypress Hills Provincial Park. 104 pp.

${ }^{3}$ Lombard North Group. 1975. Master Plan Study of Cypress Hills Provincial Park and Forest, Saskatchewan. 113 pp.

${ }^{4}$ Sask. Dept. of Tourism and Renewable Resources. 1977. Recommendations on the Cypress Hills Provincial Park Public Hearings. 8 pp.

${ }^{5}$ FORSTER, R. R. 1973. Planning for Man and Nature in National Parks. IUCN Pub. New Series No. 26. 85 pp.

${ }^{6}$ DEVRIES, B. and C. D. BIRD, 1968. Additions to the vascular flora of the Cypress Hills, Alberta. Blue Jay 26:98-100.

'BIRD, C. D. 1970. Notes on the bryophyte flora of the Cypress Hills. Blue Jay 28:129-132.

${ }^{8}$ DEVRIES, B. 1958. Orchids of the Cypress Hills. Blue Jay 16:25-26
${ }^{9}$ LOOMAN, J. 1969. The fescue grasslands of western Canada. Vegetatio 19 (12): 128-145.

${ }^{10}$ NIEMAN, D. J. and R. J. ISBISTER. 1974. Population status and management of trumpeter swans in Saskatchewan. Blue Jay 32:97-101

11SOPER, J. D. 1961. Field data on the mammals of southern Saskatchewan. Can. Field Nat. 75:23-41.

${ }^{12}$ NELSON, J. G. 1973. The Last Refuge. Harvest House Ltd., Montreal. 230 pp.

${ }^{13}$ WYLDMAN, E. C. 1954. Range Management Plan, West Block, Cypress Hills. Sask. Dept. of Nat. Resources. $38 \mathrm{pp}$.

${ }^{14}$ MC GREGOR, E. G. 1977. Management of Vegetation, Wildlife and Recreation in the West Block, Cypress Hills Provincial Park, Saskatchewan. Unpub. M. Env. Des. Project. Univ. of Calgary. 226 pp.

${ }^{15}$ KAGIS, H. 1952. Forest Management Plan, Cypress Hills West Block. Sask. Dept. of Natural Resources. 42 pp. \& appendices.

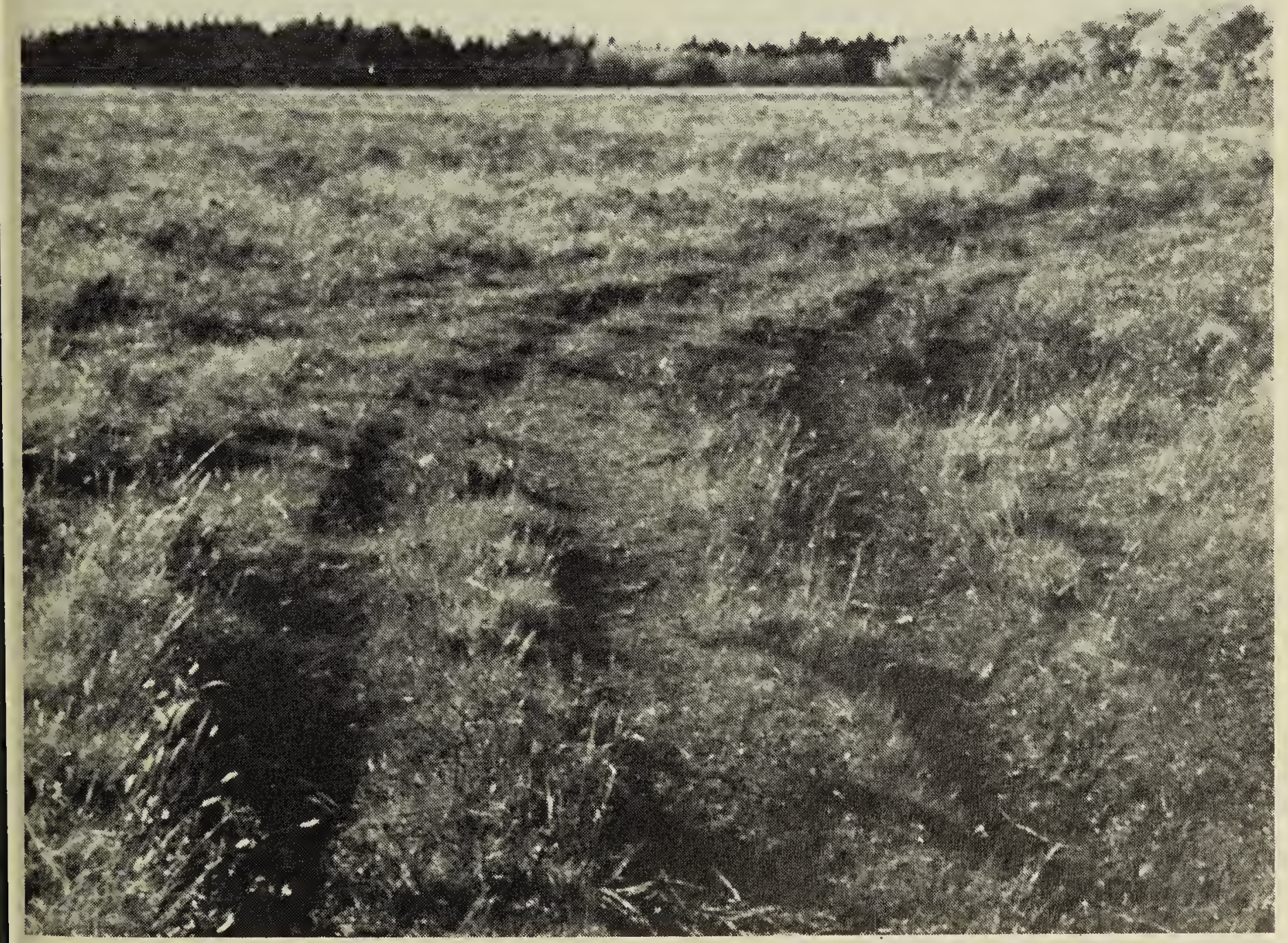

